Quim. Nova, Vol. 34, No. 2, 292-299, 2011

\title{
PHARMACEUTICAL USE OF GALACTOMANNANS
}

\author{
Joana Léa Meira Silveira \\ Departamento de Bioquímica e Biologia Molecular, Universidade Federal do Paraná, CP 19081, 81531-990 Curitiba - PR, Brasil \\ Tania Mari Bellé Bresolin* \\ Núcleo de Investigações Químico-Farmacêuticas, Universidade do Vale do Itajaí, CP 360, 88302-202 Itajaí - SC, Brasil
}

Recebido em 5/1/10; aceito em 13/8/10; publicado na web em 26/11/10

\begin{abstract}
PHARMACEUTICAL USE OF GALACTOMANNANS. The pharmaceutical use of galactomannans from different sources, commercial and noncommercial, has been extensively studied over the past decade. Galactomannans show potential in the global trend towards the use of more plant-based products for ecological motives, and their production and application do not cause pollution or disturb the ecosystem. There is a variety of galactomannan sources and various pharmaceutical forms of application, such as tablets or capsules, hydrogels and films. Besides the simple use as inert excipient this polysaccharides play role in the modification of drug release, especially in colonic environmental, as a matrix or coating material.
\end{abstract}

Keywords: galactomannans; pharmaceutical use; drug delivery.

\section{INTRODUCTION}

Polysaccharides are common in plants, microorganisms (fungi and bacteria), algae, and animals. Together with proteins and polynucleotides, they are essential biomacromolecules for life, and play an important role in cell-to-cell communication, cell adhesion, and molecular recognition in the immune system. ${ }^{1}$ In recent years, some bioactive polysaccharides isolated from natural sources have attracted much attention in the field of biochemistry and pharmacology. ${ }^{2}$

Galactomannans exhibit a wide range of new and commercially useful properties. This biopolymer constitutes the second largest group of storage polysaccharides in terms of its distribution in the plant world, and has been found as endosperm cell wall storage in the seeds of several botanical families. ${ }^{3-7}$

Galactomannans consist of a $(1 \rightarrow 4)$-linked $\alpha$-D-mannopyranosyl backbone, substituted at O-6 by single units of $\beta$-D-galactopyranose (Figure 1). The mannose/galactose ratio (M/G) varies from about 10 to 1 , depending on the plant source. $\alpha$-D-Galactopyranose residues in the side chains have a fundamental effect on solubility. The water solubility of galactomannans increases with increasing content of galactose (i.e. with decreasing $\mathrm{M} / \mathrm{G}$ ratio), presumably because the galactose substituents inhibit solid-state packing of mannan chains and contribute to conformational entropy in the solution state by freedom of rotation about the $(1 \rightarrow 6)$ linkages. A galactose substitution level of $10 \%$ is necessary for water solubility. Galactomannans with a galactose content of $<10 \%$ form precipitates at room temperature, due to the association of the nonsubstituted regions of the polymer. Solubility at lower temperatures is confined to chains whose galactose content is higher than the average value for the whole gum, and indeed fractions of different $\mathrm{M} / \mathrm{G}$ ratio can be obtained by dissolving at progressively higher temperatures. ${ }^{6,8,9}$

Galactomannans are often used in different forms for human consumption. With their different physicochemical properties, they are a versatile material with many applications. In simple aqueous systems, they are effective viscosifiers and thickeners, and are also excellent stiffeners and stabilizers of emulsions. The absence of toxicity also favors their use in the textile, pharmaceutical, biomedical, cosme-

*e-mail: tbresolin@univali.br

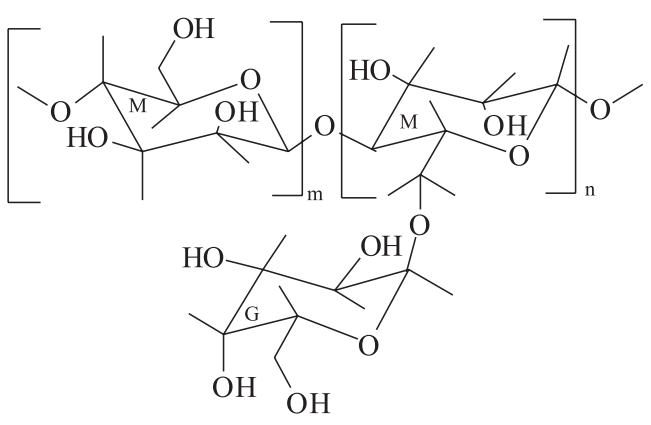

Figure 1. Generic structure of galactomannans: $M=$ mannose; $G=$ galactose

tics, and food industries. ${ }^{6,9}$ They are mainly used in pharmaceutical technology and cosmetics, not as pure galactomannan but as a crude flour. Commercially sold flours are reported to contain about $85 \%$ pure galactomannan on a mass basis and make an important contribution to the hydrocolloid usage in many products. ${ }^{10-12}$ Galactomannans have sometimes been used in binary mixtures with other polysaccharides, such as with xanthan gum, agar and kappa-carrageenan, to form gels with new properties.,13-18 The three major galactomannans of commercial importance in food and non-food industries are guar (Cyamopsis tetragonolobus, M/G 1.5), tara (Caesalpinia spinosa, $\mathrm{M} / \mathrm{G} 3$ ) and locust bean gums (Ceratonia siliqua, $\mathrm{M} / \mathrm{G} 3.5){ }^{8,19}$ Other commercial galactomannans, such as gums of Cassia tora (M/G 8.3), Trigonella foenumgraecum (M/G 1.0) and Prosopis juliflora (M/G 1.2), are also produced. . $^{5,20,21}$

The estimated worldwide annual production of locust bean gum (LBG - E 410) alone is 15,000 tons, and current prices are from 12 to 22 euros/kg or more, depending on the grade and supplier. ${ }^{19}$

There are numerous patents on guar and locust bean gum applications in developed countries. ${ }^{22-28}$ Their importance has greatly increased, due to the global trend towards the use of more plant-based products, for ecological motives. Plant-based products are considered 'generally recognized as safe' 29 and ecologically friendly, as their production and application do not cause pollution and do not disturb the ecosystem. ${ }^{6}$

Current international trends demand the introduction of alterna- 
tive sources of seed gums ${ }^{30}$ and it is therefore important to search for alternative renewable sources, for example in the production of pharmaceutical materials. In Latin America, the number of known sources of galactomannans is small, despite the rich biodiversity of the local flora and the favorable climate for their production. ${ }^{31-44}$

In 2008, Brazil imported approximately US\$ 142,000 of total polysaccharides but exported only U\$ 68,000. Guar imports represented US\$18,000 over the five-year period of 1993-2007 and around 10,000 tons, at a price of U\$1.9/kg. Thus, the country suffers a commercial deficit in this field. ${ }^{45}$

Over the last few decades, many reports have appeared on the composition and physiochemical properties of galactomannans from different plant sources. ${ }^{6,33,36-38,40-44,46-59}$ However, only guar, locust bean, tara and cassia gum are manufactured on a large scale, and these are being extensively investigated by various researchers. . $^{511,12,19,21,60-66}$ Srivastava and Kapoor ${ }^{6}$ described, in their overview of galactomannans, chemical screening of more than 300 Indian species of water-soluble gums. The vast numbers of galactomannans already isolated and structurally characterized offer an exciting challenge for pharmaceutical and other industrial producers.

\section{GALACTOMANNANS AS EXCIPIENTS IN SOLID PHARMACEUTICAL DOSAGE FORMS}

In view of the application of galactomannans in the development of solid pharmaceutical dosage forms in conventional or modified drug delivery systems, particularly tablets and capsules, many studies over the last decade have demonstrated their advantages (Table 1).

In these investigations, different types of galactomannans were used, commercial or extracted in laboratory, purified or not purified. For the tablet production, direct compression and wet granulation were used, with different results. The potential of galactomannans in the development of solid pharmaceutical dosage forms is indicated, especially in modified drug delivery systems.

Berta et al. ${ }^{67}$ analyzed the applicability of commercial galactomannan from Guar Gum under the commercial name of Meyprogat ${ }^{\circledR}$, with different molecular weight, as an auxiliary agent in tabletmaking. In low concentrations (5-10\%) as a disintegrating agent and in high concentrations (25\%) as a binding agent. Galactomannan provides tablets with a high level of hardness and is suitable for the formation of hydrophilic matrix tablets of theophylline, with different dissolution rate, according galactomannan used.

Stereoselective dissolution was evaluated for a chiral drug (verapamil hydrochloride) from matrix tablets press-coated with different chiral excipients, including the galactomannan from locust bean gum (Viscogum ${ }^{\circledR}$ HV 3000 A, Sanofi, France). ${ }^{6}$ The polymers (Hydroxypropyl Methylcellulose-HPMC, partially crosslinked amylose, pectin, galactomannan or scleroglucan), used for shell formulations of the dry-coated system, are designed to delay core hydration until the coating is completely hydrated and/or gelled, and at the same time to reduce the release rate of the drug. The interaction of the enantiomers with the excipient may lead to differentiated delivery rates from the devices, for each drug enantiomer. The polymer shells of

Table 1. Summary of studies with galactomannans in the development of solid pharmaceutical dosage forms

\begin{tabular}{|c|c|c|c|c|}
\hline Galactomannan source & Pharmaceutical dosage forms & Drug model & Function of galactomannan & Ref. \\
\hline Guar Gum (Meyprogat $\left.{ }^{\circledR}\right)$ & tablet & theophylline & disintegrant and binder & 67 \\
\hline Locust bean gum $\left(\right.$ Viscogum $\left.^{\circledR}\right)$ & press-coated tablet & verapamil $\mathrm{HCl}$ & coating & 68 \\
\hline Locust bean gum (seeds) & tablet & 5-ASA & binder & 69,70 \\
\hline $\begin{array}{l}\text { Guar Gum } \\
\text { (Supercol Guar Gum }^{\circledR} \text { ) }\end{array}$ & tablet & $\begin{array}{l}\text { - dexamethasone } \\
\text { - budesonide }\end{array}$ & binder & 71 \\
\hline Leucaena leucocephala (seeds) & tablet & paracetamol & binder & 72 \\
\hline $\begin{array}{l}\text { Guar Gum } \\
\left.\text { (Supercol Guar Gum }^{\circledR}, \text { GuarNT }^{\circledR}\right)\end{array}$ & tablet and capsules & $\begin{array}{l}\text { - ranitidine } \mathrm{HCl} \\
\text { - diltiazem } \mathrm{HCl}\end{array}$ & binder & 73 \\
\hline Lactan from Rahnella aquatilis (anaerobic bacteria) & microspheres & indomethacin & binder & 74 \\
\hline Locust bean gum crosslinked with butanedioldiglycidylether & tablet & theophylline & Film coating & 75 \\
\hline Galactomannan: pectin & tablet & nifedipine & Film coating & 76 \\
\hline Guar Gum (Meyprolin M-175 ${ }^{\circledR}$ ) & tablet & ibuprofen & disintegrant and binder & 77 \\
\hline Guar gum (seeds) & tablet & Mebendazole & binder & 78 \\
\hline Guar gum (seeds) & tablet & 5-fluorouracil & Compression coating & 79 \\
\hline Carboymethyl guar & Transdermal & Terbutaline sulfate & Film & 80 \\
\hline Guar gum and xanthan & tablet & 5-fluorouracil & Compression coating & 81 \\
\hline Galactoamannan from Gleditsia triacanthos & tablet & theophylline & binder & 10 \\
\hline Galactoamannan from Mimosa scabrella & tablet and capsules & diclofenac sodium & binder & 16 \\
\hline Galactoamannan from Mimosa scabrella & tablet & theophylline & binder & 82 \\
\hline Guar Gum/Locust Bean Gum (cross-link with glutaraldehyde) & tablet & $\begin{array}{l}\text { - teophylline } \\
\text { - vitamin B12 } \\
\text { - myglobin }\end{array}$ & binder & 83 \\
\hline Guar gum/alginate (cross-link with glutaraldehyde) & Freeze and air-dried hydrogel & Bovine serum albumin & matrix & 84 \\
\hline Locust bean gum/Xanthan (TIMERx $\left.{ }^{\circledR}\right)$ & tablet & $\begin{array}{l}\text { - oxymorphone } \\
\text { - nifedipine } \\
\text { - cybutynin }\end{array}$ & binder & $*$ \\
\hline
\end{tabular}

*Commercial product from Penwest Pharmaceutical Company 
the press-coated devices delayed the release-start and in most cases, also modulated the core release profile. The release rate was greatly reduced by the presence of the polymer shells containing HPMC, cross-linked amylose, galactomannan, and scleroglucan. Pectin, galactomannan, and scleroglucan seem to produce a slightly higher dissolution rate of $\mathrm{R}$ compared with the $\mathrm{S}$ enantiomer.

Deodhar and co-workers ${ }^{72}$ evaluated a galactomannan from the seeds of Leucaena leucocephala Lam. de Wit, which contains up to $29 \% \mathrm{w} / \mathrm{w}$ of this polymer in its seeds. This galactomannan was used as a binder in paracetamol tablets, a material which does not compress easily, in comparison with the commercial binders starch, polyvinyl pyrrolidone (PVP-K30), gelatin, and guar gum. The micromeritic properties of the paracetamol granules produced with the different binders $(8 \% \mathrm{w} / \mathrm{w})$ were compared. The galactomannan granules showed superior flow properties and the resistance of their granules to crushing, which is important for the uniformity of the granule size, was high compared with other binders (guar gum > galactomannan; gelatin $>$ starch $>$ PVP-K30). The surface strength of the granules was also appropriate (gelatin $>$ galactomannan $>$ starch $>$ PVP-K30 $>$ guar gum). In relation to granule compressibility, the galactomannan from L. leucocephala was comparable to PVP-K30 and starch, suggesting that the granules of the three binders consolidate at low pressure, giving good compacts. The authors emphasize the high potential of galactomannan from L. leucocephala as pharmaceutical binder.

Gebert and Friend ${ }^{73}$ evaluated five different commercial samples of guar galactomannan, before and after purification, according to their physicochemical properties and corresponding tablet or capsule dissolution performance. Purification reduced the protein level (initially $>5 \%$ to $<$ $0.5 \%$ ) and enhanced the soluble galactomannan fraction. The viscosity increased with all of the purified galactomannans, by $41-95 \%$. From the raw material and purified galactomannans, capsules, and tablets (by dried granulation method) were prepared. The purified galactomannan capsules of ranitidine $\mathrm{HCl}$ remained fully intact at 20 and $40 \mathrm{rpm}$ using apparatus II, in water at $37^{\circ} \mathrm{C}$, while the unpurified galactomannan capsules swelled and partially disintegrated over $2 \mathrm{~h}$. At $200 \mathrm{rpm}$ the capsule containing unpurified guar gum rapidly disintegrated within $4 \mathrm{~min}$, but the capsule containing purified guar only partially disintegrated, even after $1 \mathrm{~h}$ and $40 \mathrm{~min}$. The purified galactomannan tablets of diltiazem. $\mathrm{HCl}$ exhibited greater dissolution stirring speed independence. Tablet hardness increased with decrease in particle size of purified galactomannan and the larger particle size range tablets did not compress. The authors remark that purified guar contains $90 \%$ water-soluble galactomannan and $10 \%$ water, while the raw material is composed of $67 \%$ watersoluble galactomannan, resulting in increased viscosity of the former and consequently, gel properties of the pharmaceutical dosage forms.

Another application of galactomannan ${ }^{77}$ was in the formulation of rapid dispersion ibuprofen tablets, which are used for elderly patients and children who have difficulty swallowing conventional tablets or capsules. This technology allows high drug loading, has an acceptable taste, offers a pleasant feeling in the mouth, and leaves minimal residue in the mouth after oral administration. The authors developed two types of formulations: type I, a water dispersible tablet, and type II, a tablet which disintegrates rapidly in the mouth through the presence of saliva, by direct compression. In the former, guar gum was used (Meyprolin M-175 ${ }^{\circledR}$ ) in different concentrations as viscosity donor. This agent showed a high influence on the tablet disintegration process, as it starts to swell immediately on contact with water. Increasing amounts of the thickening agent resulted in delayed disintegration, without any effect on tablet porosity. Guar gum is not compressible and does not form compacts at $32 \% \mathrm{w} / \mathrm{w}$ of Meyprolin M-175 ${ }^{\circledR}$ in the formulation, but one containing 5\% of crospovidone and $26 \%$ Meyprolin $\mathrm{M}-175^{\circledR}$ shows an acceptable mechanical strength of $95 \mathrm{~N}$ at a compression force of $35 \mathrm{kN}$, and leads to an optimum disintegration time within $40 \mathrm{~s}$. The investigators commented on the challenge of developing a water dispersible tablet, since the disintegration step has to occur first, before the viscosity enhancer starts to swell, leading to the generation of a suspension with a higher viscosity. They concluded that the disintegration time of the water dispersible tablet is strongly influenced by porosity, applied compression force, and the presence of crospovidone and Meyprolin $\mathrm{M}-175^{\circledR}$, whereas the hardness of the tablet depended mainly on compression force and the amount of galactomannan.

Galactomannan from seeds of Gleditsia triacanthos Lin. was studied as a hydrophilic matrix (5 and 10\%) in theophylline tablets prepared by wet granulation. The dissolution behavior was compared with that of two other commercial polymers - hydroxyethylcellulose (HEC) and Hydroxypropyl Methylcellulose (HPMC) - at the same concentration and with a commercial sustained release (CSR) tablet containing $200 \mathrm{mg}$ of anhydrous theophylline and compressed from pellets. All the formulated granules showed excellent flowability and performance of compressibility into tablet form. The resulting tablets met the requirements for physical analysis. According to the results obtained from the dissolution studies in distilled water, $\mathrm{pH} 1.2 \mathrm{HCl}$ buffer and $\mathrm{pH} 7.2$ phosphate buffer, no significant difference was found between the CSR tablet and the matrix tablet containing $10 \%$ of galactomannan in each medium. These tablets showed a zero-order kinetic of drug release in all media. ${ }^{10}$

The use of galactomannans as hydrophilic matrix provided a drug delivery system, which process of drug delivery is monitored by diffusion and erosion of the matrix, as show in Figure 2.

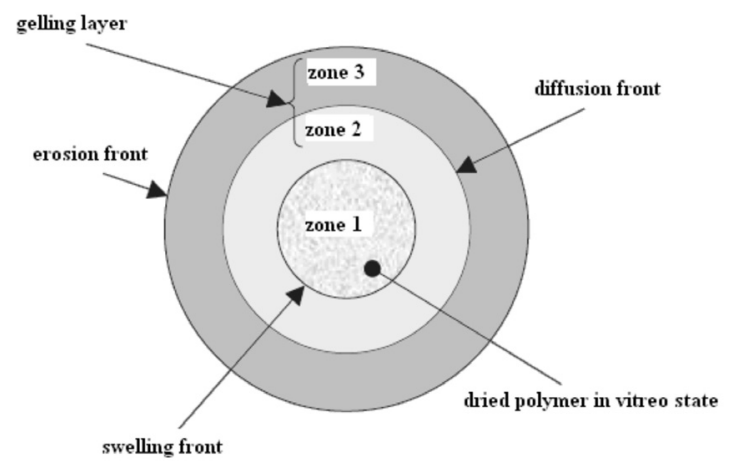

Figure 2. Illustration of fronts (swelling, diffusion and erosion) during the drug delivery by matrix swelling process. Adapted from ref. 85

In macroscopic view of matrix swelling process from the center to peripheral area it can be see three concentric circles: swelling front, diffusion front and erosion front (Figure 2). In the zone 1, the polymer is in dry state with the glass transition temperature (Tg) higher than experimental temperature. At interface of zone 1 and 2 (swelling front) there is the polymer hydration and swelling. In the zone 2 the hydrated polymer shows decrease of the Tg that remains lower than experimental temperature and higher mobility of polymer chains. In this zone there is the gelation of polymer and the drug remains partially undissolved. In the zone 3 the drug is dissolved and the diffusion front is related with the dissolution drug velocity. The dissolved drug moves to erosion front that is the interface between de medium of dissolution and the matrix. In this zone the polymer chains become disentangled and dissolved and the drug is released by erosion of the system. ${ }^{85}$

A common galactomannan substitute, from seeds of Mimosa scabrella Bentham (M:G 1.1:1), a leguminous Brazilian tree, in a mixture with xanthan, an exopolysaccharide secreted by Xanthomonas campestris $\left(\mathrm{Keltrol}^{\circledR}\right)$, was evaluated for controlled release of diclofenac sodium in tablets and capsules. ${ }^{6}$ Two formulations were 
developed, with 50 and $100 \mathrm{mg}$ of drug/unit and final gum:drug ratios of 16:1 and 8:1 respectively. The drug release performance of the matrices was compared with that of a commercial controlled release product of diclofenac sodium. Very low percentages of dissolved diclofenac sodium were observed at a $\mathrm{pH}$ of 1.4 to 4.0 over $2 \mathrm{~h}$, followed by progressive increases of dissolved diclofenac sodium at $\mathrm{pH}$ 6.8. All the formulations gave rise to more drug retention than the commercial product, with a drug release of 78.6 and $35.1 \%$ after 24 $\mathrm{h}$ for capsules and tablets respectively, in contrast to the commercial product $(92.5 \%)$. The tablets produced zero order model drug release, where erosion of the gel controls release rather than diffusion, and the capsules were of a first order model. The $n$ values, from the Peppas and Sahlin ${ }^{86}$ exponential equation, revealed Super Case II transport for these matrices. The results indicate the potential of galactomannan: xanthan systems as release retarding materials.

Another work on the galactomannan:xanthan mixture was carried out by Vendruscolo et al.. ${ }^{82}$ Directly compressed theophylline tablets were obtained, containing commercial Xanthan (Keltrol $\left.{ }^{\circledR}\right)$ and galactomannan from the seeds of Mimosa scabrella, as release-controlling agents. Gums were used at 4, 8, 12.5 and $25 \%$ w/w, either alone or in a mixture (xanthan: galactomannan 1:1). During the galactomannan extraction process, it was dried in a scale up, using a vacuum oven (GVO) or spray dryer (GSD). Matrix granules of theophylline and lactose were prepared by the wet granulation method using $70 \%$ ethanol. The tablets containing GSD resulted in a more uniform drug release than the GVO tablets, due to their smaller particle size. Drug release decreased with increase of polymer concentration, and all the formulations at $25 \% \mathrm{w} / \mathrm{w}$ of gums showed an excessive sustained release effect (about $45 \%$ drug release after $8 \mathrm{~h}$ ). The matrices made with xanthan alone showed higher drug retention, at all concentrations, compared with galactomannan matrices that released the drug too quickly. The xanthan: galactomannan matrices were able to produce near zero order drug release. The xanthan:GSD $8 \%$ tablets provided the required release rate (about $90 \%$ after $8 \mathrm{~h}$ ), with zero order release kinetics. The tablets containing GVO in low concentrations showed complete erosion, while the GSD demonstrated fast hydration and swelling, in contact with the dissolution medium. The release mechanism was a combination of diffusion and relaxation. The relative importance of these two processes varied with matrix composition. The xanthan:GSD $8 \%$ matrix gave a higher contribution of polymer relaxation.

In order to analyze the effect of the galactomannan drying method on powder quality, following its extraction from the seeds of M. scabrella, and its applicability as excipient in solid dosage forms, Vendruscolo et al.$^{87}$ extracted galactomannan on a pilot plant scale and dried it with a vacuum oven (GVO) or spray-drier (GSD). The products were analyzed by high performance size exclusion chromatography (HPSEC) coupled with a multiangle laser light scattering (MALLS) and refractive index (RI) detectors. The former gives a signal proportional to concentration, whereas the latter response depends on both concentration and molar mass (Mw). When neutral polysaccharides, such as galactomannans, are dissolved in water, macromolecular aggregates are inevitably present via intermolecular hydrogen bonding between hydroxyl groups, ${ }^{88,89}$ which could lead to inaccurate size measurements. The analysis of GVO and GSD by this technique showed a higher Mw for GSD, and both products presented polydispersed elution profiles. The results suggest that both products behave as semi-flexible polymers, although GSD showed more aggregation at molecular level $(\sim 10 \%)$ and greater chain stiffness (Persistence Length- Lp of $9.1 \mathrm{~nm}$ ). The authors suggest that the spray drying process leads to higher chain entanglement, resulting in higher aggregation at molecular level in GSD. X-Ray diffraction confirmed the amorphous nature of both galactomannans, although GSD showed high crystallinity, in agreement with the slower decomposition and higher ash content for GSD observed in the thermal analysis. The GSD showed less density $\left(1.009 \mathrm{~g} / \mathrm{cm}^{3}\right)$, high cohesiveness (repose angle $35.5^{\circ}$, compressibility $32.2 \%$ and absence of flow), with smaller and more spherical particles than the GVO sample, both with high polydispersion. As vacuum oven drying resulted in fibrous material, the authors arguing that spray drying is an alternative method which is easy to extrapolate by industrial processes, requiring the incorporation of a glidant to improve powder flowability.

The drug dissolution profile (theophylline, vitamin B12, and myglobin) from hydrogels of galactomannans of guar and locust bean gum or from tablets obtained with these lyophilized polymers were studied (reference tablets) ${ }^{83}$ It as also evaluated the pharmaceutical dosage forms elaborated with crosslinked galactomannans. The theophylline was completely delivered (in water $\mathrm{pH} 5.4$, basket at $100 \mathrm{rpm}$ ) within the first $8 \mathrm{~h}$ from hydrogel of guar galactomannan crosslinked with glutaraldehyde, while myglobin showed an initial slight release or burst effect (almost $20 \%$ ) after just $15 \mathrm{~min}$, but no further increase thereafter $(24 \mathrm{~h})$, attributed to the high radius of myglobin. The total release of theophylline from the crosslinked locust bean gum hydrogel was faster $(3 \mathrm{~h})$, due to the lower number of crosslinks formed in this polymer. In the reference tablets the drug delivery follows a trend related to the molecular dimensions of the drugs (theophylline $>$ vitamin B12 > myglobin). In this system, after $24 \mathrm{~h}$, only $40 \%$ of the loaded drug was delivered, due to the partial erosion of the matrix. In the guar galactomannan tablets, for the smaller theophylline molecule, crosslinking increased drug release, attributed to the meshes introduced by the crosslinked agent in the matrix. This effect was more evident in the guar galactomannan due to its higher degree of substitution. In the presence of crosslinking, the resistance to drug diffusion is lower than in the non-crosslinked systems at the beginning of the dissolution test. The authors point out the possibility of modulating the release of drugs of different size from hydrogels and the corresponding tablets prepared with galactomananans and glutaraldehyde as crosslinker.

Murthy et al..$^{80}$ evaluated carboxymethyl guar films for the formulation of transdermal drug delivery systems, using terbutaline sulfate as a model. The films were developed by the casting method and their physical properties were tested. They exhibited good film forming ability, and were non-sensitizing and safe for dermal application. Drug diffusion was slower at $\mathrm{pH} 5$ than at 10 , following zero order across human cadaver epidermis. The bioavailability of the drug was $50 \%$ higher in $\mathrm{pH} 5$ formulations than under $\mathrm{pH} 10$ conditions. The authors argue in favor of the low cost of this semisynthetic polymer, in comparison with synthetic polymers currently used in transdermal systems.

A drug delivery tablet system of LBG with xanthan, commercially known as TIMERx ${ }^{\circledR}$, was developed by the Penwest Pharmaceuticals Company. ${ }^{90}$ It now uses newer generations of this technology; the Geminex ${ }^{\circledR}$, which is a two-layer tablet press, and the SyncroDo$\mathrm{se}^{\mathrm{TM}}$, an inner core of drug surrounded by a compression coating, containing TIMERx ${ }^{\circledR}$ based material. The company's portfolio has increased with five approved drugs which use TIMER ${ }^{\circledR}$ technology, and there are a further two products in the pipeline, currently in the development phase.

These investigations show the potential of many galactomannans, particularly from seeds of leguminous plants, in the area of solid pharmaceutical dosage forms. Industrial use of isolated galactomannans for this purpose faces some challenges, such as the variability of purity grade and molecular weight, which is influenced by the extraction and isolation method. But the industrial pharmaceutical application of galactomannans in mixture with other biopolymers is a reality. Their versatility enables potential new developments for different drug delivery systems in this field. 


\section{GALACTOMANANNS AS A COMPONENT OF HYDROGELS}

Considering that isolated galactomannan did not form a gel, the possibility of their derivatization, grafting, and crosslinking, and consequent generation of unique hydrogel material have been exploited. ${ }^{91-100}$ The binary mixture of galactomannans with other biopolymers has also been studied, especially with xanthan ${ }^{14,15,18,101-108}$ that enables gel formation and potential drug entrapment, for the development of modified drug delivery systems.

More recently, Rinaudo and Moroni ${ }^{18}$ pointed out the potential of ternary mixtures xanthan:galactomannan:methylcellulose for application in drug delivery systems for food, in which hydrophilic gels with good thermal and $\mathrm{pH}$ stability are required.

Soppimath et al. ${ }^{109}$ prepared spherical crosslinked hydrogels of polyacrylamide-grafted guar gum by emulsification. These were derivatized by saponification of $-\mathrm{CONH}_{2}$ to $-\mathrm{CO}_{2} \mathrm{H}$ groups.

The $\mathrm{pH}$-sensitive microgels were loaded with diltiazem hydrochloride by soaking in an aqueous solution containing $10 \%$ of the drug. They explained the swelling mechanism in terms of the relaxation-controlled phenomenon in both acidic and basic $\mathrm{pH}$ conditions, and in ionic solution $(1.0 \mathrm{M} \mathrm{NaCl})$. The release of diltiazem hydrochloride followed non-Fickian transport in almost all cases. Drug release was dependent on their solubility, and on the $\mathrm{pH}$ of the medium with a quicker release in $\mathrm{pH} 7.4$ buffer, compared with $0.1 \mathrm{M} \mathrm{HCl}$.

The release of two prodrugs, L-tyrosine and 3,4-dihydeoxy phenylalanine (L-DOPA), from acryloyl guar gum and its hydrogel material, was recently evaluated. ${ }^{110}$ These hydrogels exhibited unique swelling behavior and respond well to physiological stimuli, such as $\mathrm{pH}$ and ionic strength. The release was slow, especially at $\mathrm{pH}$ 7.4. The hydrogel materials based on poly(acrylic acid) and poly(methacrylic acid) released the greatest amount of L-tyrosine and L-DOPA respectively, in both media (acid and alkaline). They pointed out the slow release behavior of hydrogel materials, based on poly(2-hydroxyethyl methacrylate) and poly(2-hydroxypropyl methacrylate) even after 12 $\mathrm{h}$, and the potential use of these devices in transdermal applications for the treatment of diseases, such as vitiligo and Parkinson's.

Koop et al. ${ }^{17}$ evaluated the rheological properties of a physically linked hydroalcoholic gel obtained from a binary system consisting of xanthan and galactomannan from the seeds of Mimosa scabrella and compared them to those of guar gum. Rheological analysis demonstrated an improvement of strength of binary hydrogels after dispersion of the polysaccharides in buffer plus 1,2-propanediol. The addition of ascorbic acid to these hydrogel formulations resulted in a slight decrease in gel strength. Both hydrogels were rheologically stable over 12 weeks at ambient temperature.

\section{USE OF GALACTOMANNANS IN COLON-SPECIFIC DRUG DELIVERY}

In the last two decades, colon targeted drug delivery has increased in importance, not only for the delivery of drugs to treat various colonic diseases (such as irritable bowel syndrome, inflammatory bowel disease, including Crohn's disease, and ulcerative colitis), but also for its potential for delivery of proteins and therapeutic peptides, due to the relatively low proteolytic enzyme activity in this site. Various traditional approaches used for colon targeted delivery have achieved limited success. ${ }^{111,112}$ Examples of such approaches include prodrugs (cleavage of the linkage bond between drug and carrier via reduction, and hydrolysis by enzymes from colon bacteria), $\mathrm{pH}$-dependent systems (combination of polymers with $\mathrm{pH}$-dependent solubility to take advantage of the $\mathrm{pH}$ changes along the GI tract), time-dependent systems (the onset of drug release is aligned with positioning the delivery system in the colon by incorporation a time factor which simulates the system transit in the upper gastrointestinal tract), and microflora activated systems (primarily, fermentation of non-starch polysaccharides by colon anaerobic bacteria, incorporating the polysaccharide via film-coating and matrix formation). In the latter case (microflora activated systems), galactomannans can be used to deliver drugs to the colon due their susceptibility to microbial degradation in the large intestine.

For successful colon-targeted drug delivery, the drug needs to be protected from absorption and/or the environment of the upper gastrointestinal tract, and then abruptly released into the colon. ${ }^{12}$

\section{Matrix systems}

Exploiting the three latter approaches mentioned above, many works have been carried out to develop galactomannan-based matrix systems.

As an example of the matrix system, Friend and Wong ${ }^{69,70}$ prepared tablets containing a powdered mixture of corticosteroid, 5-ASA and the galactomannan from locust bean, tragacanth, or karaia gums. They reported on the ability of these systems to guarantee therapeutically effective release of the drug in the lower gastrointestinal tract, particularly the colon, without significant release in the upper gastrointestinal tract.

Wong et al. ${ }^{71}$ discussed the problems involved in the dissolution tests during the development of guar gum-based formulation for colonic delivery, in which human stool suspensions were used as colonic fluid to evaluate drug released from potential candidates in a three-part dissolution setup (i.e. simulated gastric fluid-SGF, simulated intestinal fluid-SIF and stool suspension). In order to explain the incomplete dissolution of the "colonic release" tablets during 24 $\mathrm{h}$ in stool suspension, they argued in favor of incomplete recovery of dexamethasone during the extraction steps, low drug solubility, drug instability in the stool suspension, or variable enzyme content between stool samples. In view of these problems, they evaluated the performance of the reciprocating cylinder dissolution apparatus (USP Dissolution Apparatus III) for testing colonic delivery systems (tablets with guar gum $-60.5 \%$ and low viscosity grade HPMC- $36 \%$ obtained by direct compression). Dip speed was analyzed first in SGF, and then in SIF, in simulated colonic fluid-SCF. They determined a dip speed of 20 and 3 cycles/min for the SGF and SCF, respectively. The release of dexamethasone and budesonide from the tablets proved to be enzymatically triggered in SCF, while endo-glactomannanase accelerated dissolution of both drugs at concentrations of $>0.01 \mathrm{mg} /$ $\mathrm{mL}$. The authors conclude that guar gum-based tablets may be a useful biodegradable polymeric matrix material for delivery and release in the distal ileum, cecum and colon, and that the dissolution system tested is simple and easy to use for this purpose.

Krishnaiah et ll $^{78}$ studied guar gum-based colon tablets of mebendazole compared with an immediate release tablet in human volunteers. The matrix tablets of mebendazole were prepared by wet granulation with $20 \%$ of guar gum. Colon-targeted tablets showed delayed tmax and absorption time, and decreased $\mathrm{C}_{\max }$ and constant absorption rate, when compared with the immediate release tablets. The authors discuss the role of guar gum, which did not release the drug into the stomach and small intestine, but delivered the drug directly to the colon, resulting in slow absorption of the drug and making it available for local action in the colon.

In order to increase in hydrophobicity of some polysaccharides, such as that from guar gum, they have been chemically modified. ${ }^{113}$

Rubinstein and Gliko-Kabir ${ }^{114}$ developed a guar galactomannan cross-linked with borate ions that released only $20 \%$ of the hydro- 
cortisone in an enzyme-free dissolution medium. In contrast, the drug was completely released when the medium contained enzymes.

Burke et al. ${ }^{115}$ developed a potential platform for oral colon specific drug delivery, based on the use of $\alpha$-galactosidase to cleave off the galactose side-chains from guar galactomannan hydrogels formed through limited amounts of titanium crosslink. They evaluated the diffusion coefficient of a fluorescent probe, fluorescein isothiocyanate (FITC), a model drug in crosslinked galactomannan hydrogel, using confocal laser scanning microscopy. They discussed the degradation of the product by colonic enzymes, and consequent release of FITC. The cross-linking of guar galactomannan with glutaraldehyde increased the entrapment efficiency of the drug and slowed down the dissolution of protein (BSA) from alginate at higher intestinal $\mathrm{pH}$ levels, ensuring controlled release of the entrapped drug. ${ }^{84}$ The best alginate: guar galactomannan ratio was 3:1 with $0.5 \%$ of glutaraldehyde.

\section{Film coating}

In addition to studies in which galactomannans were used in matrix tablets or hydrogels, the employment of galactomannan in film coating, to produce a colon drug delivery system, has long been exploited as a microbiologically degradable, film coating material, for site-specific drug delivery to the colon.

One such example is the galactomannan from LBG, cross-linked with butanediol diglycidyl ether, which was investigated by Hirsch et al.. ${ }^{75}$ Theophylline biconcave tablets $(9 \mathrm{~mm}$-cores with $100 \mathrm{mg}$ of theophylline and excipients) were coated with a Hüttlin Kugel coater having coatings of $4-17 \mathrm{mg} / \mathrm{cm}^{2}$. Sprayable coating formulations were obtained with $4 \%$ aqueous dispersions of crosslinked galactomannan in a 1:1 mixture of 1-propanol and water. Theophylline dissolution was monitored using a USP XXIII paddle dissolution apparatus with a pH 5.5. After $4 \mathrm{~h}$, which is the transit time for an average small intestine, colon conditions were simulated by adding galactomannanase or dextranase, respectively. In the first $4 \mathrm{~h}$, an almost linear dissolution of theophylline occurred with a relatively quick disintegration after enzyme addition. Both parameters decreased with increasing coating. All swollen materials exhibited low mechanical stability. Crosslinked galactomannan coatings, especially with greater amounts, showed small transient ruptures at the edges not caused by enzyme addition. This behavior was explained by internal stress, due to the high degree of swelling. Coatings of cross-linked galactomannan consist of internally cross-linked small particles, whereas, binding between particles is probably achieved by hydrogen bonds and interpenetration of the outer polymer chains. During the coating process, the particles, swollen homogeneously in all three dimensions, was sprayed onto the tablet surface. Such adhesion led to mainly vertical drying. The next swollen particles hit upon a dry surface and by repetition of this process, a consistent film was formed. During rehydration, all single particles tended to regain their initial dimensions. Due to the curvature of the tablet surface, the upper layers of cross-linked galactomannan -particles were then stressed and the film could split. As the amount of coating was increased, the tension in the upper layer, and consequently, the probability of failure also increased. The authors pointed out that this is a basic problem with films that consist of cross-linked particles with a high degree of swelling, but emphasize the potential use of the cross-linked galactomannan as degradable coating material.

Thus, continuous efforts are being made to design colon-targeted drug delivery systems with improved site specificity and versatile drug release kinetics, so as to fulfill specific therapeutic needs. In the last few years, in addition to the few new systems that have been developed for colon targeted drug delivery, pectin and galactomannan coatings have been mentioned, and were reported to have better in vivo site specificity and design rationale than for earlier approaches. ${ }^{112}$
The combination of pectin and galactomannan for this type of technology was initially proposed by Lee et al.. ${ }^{116}$ The isolated polysaccharide cannot be used as a drug carrier for colon-specific delivery, due to its high water solubility and swelling characteristics. However, the researchers observed that the characteristic of the two-polysaccharide mixture depends mainly on the $\mathrm{pH}$ of the coating solution (in a $\mathrm{pH} \geq 7$ solution, the mixture resulted in strong, elastic, insoluble coatings in simulated gastric and intestinal fluids, while in a $\mathrm{pH} \leq 7$ solution, the coating rapidly dissolved in the simulated intestinal fluids). They attributed this to hydrogen bonding, hydrophobic and formation of an interjection zone arising from conformational changes of polysaccharides at the higher $\mathrm{pH}$. It was also observed that greater percentages of galactomannan in the mixture resulted in decreased bacterial degradation in the colon, and prolonged duration of negligible drug release (nifedipine) in the upper GI tract. The specific mixture of pectin and galactomannan may have the advantage of faster in vivo degradation, compared with other mixtures (pectin/ethyl cellulose or amylose/ ethyl cellulose), since both polysaccharides are readily degradable by colon microflora. ${ }^{11}$

Besides film coating, the technique of compression coating for colonic-targeted tablets has also been studied. In vitro colon specific drug delivery of 5-fluorouracil has been evaluated using guar galactomannan-xanthan and starch-based delivery devices. Polymers with different proportions were used in compression coating for rapidly disintegrating core tablets of 5-fluorouracil. ${ }^{81} \mathrm{~A}$ highly retarded drug release, proportional to the ratio of the gums used, was observed even after $24 \mathrm{~h}$ of tablet dissolution, with drug releases of 25, 36.6 and $42.6 \%$ respectively in guar galactomannanxanthan ratios of 20:20, 10:20 and 20:10 tablets in simulated gastric $(\mathrm{pH} 1.2)$ and small intestinal media ( $\mathrm{pH}$ 6.8). In rat cecal content media, the drug release with guar galactomannan-xanthan (20:10) increased to 67.2 and $80.3 \%$ respectively resulting in 2 and $4 \%$ of cecal content after $19 \mathrm{~h}$ of incubation. They discuss the successful use of xanthan as a drug release retarding agent, in combination with colon degradable polysaccharides, guar and starch, to protect the drug from being released under conditions mimicking mouthto-colon transit.

Krishnaiah et al. ${ }^{79}$ compared guar gum-based colon targeted tablets of 5-fluorouracil with an immediate-release tablet, by studying in vitro dissolution and in vivo pharmacokinetic in human volunteers. This involved preparation of fast disintegrating core tablets of 5-fluorouracil by direct compression, using spray-dried lactose and other excipients, and a compression coating formulation containing $80 \%$ of guar gum. Colon-targeted tablets not only protected the drug from being released in the physiological environment of the stomach and small intestine, but also released it into the colon by colonic bacteria. In the in vivo studies, these systems delayed the $t_{\max }$, delayed absorption time, decreased $\mathrm{C}_{\max }$, and decreased the constant absorption speed when compared with the immediate release tablets.

\section{CONCLUSION}

The studies reported herein indicate the potential pharmaceutical uses of galactomannans from different sources. The wide range of potential pharmaceutical applications of galactomannans may be an important factor for the economic and social growth of developing countries that possess a rich biodiversity for safe exploitation, and may provide an alternative to synthetic or semisynthetic polymers currently used in the pharmaceutical industry.

\section{ACKNOWLEDGMENTS}

The authors wish to thank the Brazilian agencies Conselho Nacional de Desenvolvimento Científico e Tecnológico-CNPq (Rede 
Nanoglicobiotec: Proc. No 555169/2005-7), Fundação Araucária, and PRONEX (Carboidratos) for financial support .

\section{REFERENCES}

1. Dwek, R. A.; Chem. Rev. 1996, 96, 683.

2. Yang, L.; Zhang, L-M.; Carbohydr. Polym. 2009, 76, 349.

3. Dey, P.; Adv. Carbohydr. Chem. Biochem. 1978, 35, 341.

4. Scherbukhin, V. D.; J. Appl. Biochem. Microbiol. 1993, 29, 599.

5. Daas, P. J. H.; Grolle, K.; Vliet, T. V.; Schols, H. A.;de Jongh, H. H. J.; J. Agric. Food Chem. 2002, 50, 4282.

6. Srivastava, M.; Kapoor, V. P.; Chem. Biodiversity 2005, 2, 295.

7. Lucyszyn, N.; Reicher, F.; Sierakowski, M. R.; Met. Mat. Process. 2005, $17,173$.

8. Dea, I. C. M.; Morrison, A.; Adv. Carbohydr. Chem. Biochem. 1975, 31, 241.

9. Dea, I. C. M. In Industrial Polysaccharides, Genetic Engineering, Structure/Property Relations and Applications Progress in Biotecnology; Yalpani, M., ed.; Elsevier Science: Amsterdan, 1987, vol. 3.

10. Ülner, M.; Altınkurt, T.; Il Farmaco 2004, 59, 567.

11. Pollard, M. A.; Fischer, P.; Curr. Opin. Colloid Interface Sci. 2006, 11, 184.

12. Pollard, M. A.; Kelly, R.; Fischer, P.; Windhab, E.; Eder, B.; Amado, R.; Food Hydrocolloids 2008, 22, 1596.

13. Fernandes, P. B.; Gonçalves, M. P.; Doublier, J. L. ; Carbohydr. Polym. 1991, 16, 253.

14. Goycoolea, F. M.; Richardson, R. K.; Morris, E. R.; Gidley, M.; J. Macromolecules 1995, 28, 8308 .

15. Bresolin, T. M. B.; Milas, M.; Rinaudo, M.; Reicher, F.; Ganter, J. L. M. S.; Int. J. Biol.Macromol. 1999, 26, 225.

16. Ughini, F.; Andreazza, I. F.; Ganter, J. L. M. S.; Bresolin, T. M. B.; Int. J. Biol. Macromol. 2004, 271, 197.

17. Koop, H. S.; Praes, C. E. O.; Reicher, F.; Petkowicz, C. L. O.; Silveira, J. L. M.; Mater. Sci. Eng., C 2009, 29, 559.

18. Rinaudo, M.; Moroni, A.; Food Hydrocolloids 2009, 23, 1720.

19. Dakia, P. A.; Blecker, C.; Robert, C.; Wathelet, B.; Paquot, M.; Food Hydrocolloids 2008, 22, 807.

20. Maier, H.; Anderson, M.; Karl, C.; Maqnuson, K.; Whistler, R. L. In Industrial Gums: Polysaccharides and their Derivatives; Whistler, R. L.; BeMiller, J. N., eds.; Academic Press: New York, 1993, $3^{\text {rd }}$ ed.

21. Funami, T.; Kataoka, Y.; Noda, S.; Hiroe, M.; Ishihara, S.; Asai, I.; Takahashi, R.; Nishinari, K.; Food Hydrocolloids 2008, 22, 763.

22. Rutenberg, M. W.; Molnar, T. R.; US pat. 42699751981.

23. Saud, A.; US pat. 47042241987.

24. Applegren, C. H.; US pat. 47540271988.

25. Habich, A.; Braun, J.; W.O. pat. 0747072005.

26. Hoppe, H-U.; Wenk, H. H.; W.O. pat. 0543002005.

27. Kesavan, S.; Neyraval, P.; Boukhelifa, A.; W.O. pat. 0391942006.

28. Staudigel, J. A.; Peffly, M. M.; W.O. pat. 0116772009

29. Hallagan, J. B.; La Du, B. N.; Pariza M. W.; Putnam, J. M.; Borzelleca, J. F.; Food Chem. Toxicol. 1997, 35, 625.

30. Joshi, H.; Kapoor, V. P.; Carbohydr. Res. 2003, 338, 1907.

31. Buckeridge, M. S.; Dietrich, S. M. C.; Revista Brasileira de Botânica 1990, 13, 109.

32. Buckeridge, M. S.; Panegassi, V. R.; Rocha, D. C.; Dietrich, S. M. S.; Phytochemistry 1995, 38, 871.

33. Ganter, J. L. M. S.; Reicher, F.; Bioresour. Technol. 1999, 68, 55.

34. Paganessi, V. R.; Serra, G. E.; Buckeridge, M. S.; Ciência e Tecnologia de Alimentos 2000, 20, 406.

35. Reicher, F.; Ganter, J. L. M. S.; Lajolo, F. M. In Fibra Dietética en Iberoamérica: Tecnología y Salud; Lajolo, F. M.; Saura-Calixto, F.; Penna, E. W.; Menezes, E. W., orgs.; Varela: São Paulo, 2001.

36. Ganter, J. L. M. S.; Milas, M., Corrêa, J. B. C.; Reicher, F.; Rinaudo, M.; Carbohydr. Polym. 1992, 17, 171.
37. Ganter, J. L. M. S.; Zawadzki-Baggio, S. F.; Leitner, S. C. S.; Sierakowski, M. R.; Reicher, F.; J. Carbohydr. Chem. 1993, 12, 753.

38. Ganter, J. L. M. S.; Heyraud, A.; Petkowicz, C. L. O.; Rinaudo, M.; Reicher, F.; Int. J. Biol. Macromol. 1995, 17, 13.

39. Ganter, J. L. M. S.; Cardoso, A. T. M.; Kaminski, M.; Reicher, F.; Int. J. Biol. Macromol. 1997, 21, 137.

40. Ganter, J. L. M. S.; Sabbi, J. C.; Reed, W. F.; Biopolymers 2001, 59, 226.

41. Azero, E. G.; Andrade, C. T.; Polym. Test. 2002, 21, 551.

42. Sciarinia, L. S.; Maldonado, F.; Ribotta, P. D.; Perez, G. T.; Leon, A. E.; Food Hydrocolloids 2009, 23, 306.

43. Cunha, P. L. R.; Vieira, I. G. P.; Arriaga, A. M. C.; de Paula, R. C. M.; Feitosa, J. P. A.; Food Hydrocolloids 2009, 23, 880.

44. Cerqueira, M. A.; Pinheiro, A. C.; Souza, B. W. S.; Lima, A. M. P.; Ribeiro, C.; Miranda, C.; Teixeira, J.; Moreira, R. A.; Coimbra, M. A.; Gonçalves, M. P.; Vicente A. A.; Carbohydr. Polym. 2009, $75,408$.

45. Cunha, P. L. R.; de Paula, R. C. M.; Feitosa, J. P. A.; Quim. Nova 2009, 32,649 .

46. Kapoor, V. P.; Milas, M.; Taravel, F. R.; Rinaudo, M.; Carbohydr. Polym. 1994, 25, 79 .

47. Kapoor, V. P.; Milas, M.; Taravel, F. R.; Rinaudo, M.; Food Hydrocolloids 1996, 10, 167.

48. Vargas-Rechia, C. G.; Sierakowski, M. R.; Ganter, J. L. M. S.; Reicher, F.; Int. J. Biol. Macromol. 1995, 17, 409.

49. Petkowicz, C. L. O.; Sierakowski, M. R.; Ganter, J. L. M. S.; Reicher, F.; Phytochemistry 1998, 49, 1 .

50. Sierakowski, M. R.; Milas, M.; Desbrières, J.; Rinaudo, M.; Carbohydr. Polym. 2000, 42, 51 .

51. Chaubey, M.; Kapoor, V. P.; Carbohydr. Res. 2001, 332, 439.

52. Brummer, Y.; Cui, W.; Wang, Q.; Food Hydrocolloids 2003, 17, 229.

53. Smirnova, N. I.; Mestechkina, N. M.; Scherbukhin, V. D.; Appl. Biochem. Microbiol. 2004, 40, 517.

54. Gonçalves, M. P.; Torres, D.; Andrade, C. T.; Azero, E. G.; Lefebvre, J.; Food Hydrocolloids 2004, 18, 181.

55. Garros-Rosa, I.; Reicher, F.; Petkowicz, C. L. O.; Sierakowski, M.-R.; Moreira, R.; Polímeros: Ciência e Tecnologia 2006, 16, 99.

56. Vieira, I. G. P. V.; Mendes, F. N. P.; Gallão, M. I.; de Brito, E. S.; Food Chem. 2007, 101, 70.

57. Singh, V.; Pandey, M.; Srivastava, A.; Srivastava, V.; Fitoterapia 2007, $78,268$.

58. Bouzouita, N.; Khaldi, A.; Zgoulli, S.; Chebil, L.; Chekki, R.; Chaabouni, M. M.; Thonart, P.; Food Chem. 2007, 101, 1508.

59. Singh, V.; Sethi, R.; Tiwari, A.; Int. J. Biol. Macromol. 2009, 44, 9.

60. Huang, X.; Kakuda, Y.; Cui, W.; Food Hydrocolloids 2001, 15, 533.

61. Daas, P. J. H.; Schols, H. A.; de Jongh, H. H. J. ; Carbohydr. Res. 2000, 329, 609.

62. Sittikijyothin, W.; Torres, D.; Gonçalves, M. P. ; Carbohydr. Polym. 2005, 59, 339.

63. Pollard, M. A.; Kelly, R.; Wahl, C.; Fischer, P.; Windhab, E.; Eder, B.; Amado, R. ; Food Hydrocolloids 2007, 21, 683.

64. Morris, G. A.; Patel, T. R.; Picout, D. R.; Ross-Murphy, S. B.; Ortega, A.; Torre, J. G.; Harding, S. E.; Carbohydr. Polym. 2008, 72, 356.

65. Tapie, N.; Malhiac, C.; Hucher, N.; Grisel M.; J. Chromatogr., A 2008, 1181,45 .

66. Shobha, M. S.; Tharanathan, R. N.; Food Hydrocolloids 2009, 23, 749.

67. Berta, E.; Hódi, K.; Révész, P.; Miseta, M.; Selmeczi, B.; Acta Pharmaceutica Hungarica 1994, 64, 26.

68. Maggi, L.; Massolini, G.; De Lorenzi, E.; Conte, U.; Caccialanza, G.; Int. J. Pharm. 1996, 136, 43.

69. Friend, D.; Wong, D.; W.O. pat. 400781996.

70. Friend, D.; Wong, D.; US pat. 5.656.294 1997.

71. Wong, D.; Larrabee, S.; Clifford, K.; Tremblay, J.; Friend, D. R.; J. Controlled Release 1997, 47, 173. 
72. Deodhar, U. P.; Paradkar, A. R.; Purohit, A. P.; Drug Dev. Ind. Pharm. 1998, 24, 577.

73. Gebert, M. S.; Friend, D. R.; Pharm. Dev. Technol. 1998, 3, 315.

74. Na, K.; Lee, K-Y.; Drug Dev. Ind. Pharm. 1998, 24, 563.

75. Hirsch, S.; Binder, V.; Schehlmann, V.; Kolter, K.; Bauer, K. H.; Eur. J. Pharm. Biopharm. 1999, 47, 61.

76. Pai, C. M.; Lim, C. B.; Lee, S. J.; Park, I.; Seomoon, G.; Connor, A. L.; Wilding, I. R.; Proceedings of the International Symposium on Controlled Release Bioactive Materials, 2000, vol. 27.

77. Schiermeier, S.; Schmidt, P. C.; Eur. J. Pharm. Sci. 2002, 15, 295.

78. Krishnaiah, Y. S. R.; Raju, P. V.; Kumar, B. D.; Satyanarayana, V.; Kanthikeyan, R. S.; Bhaskar, P.; J. Controlled Release 2003, 88, 95.

79. Krishnaiah, Y. S. R.; Satyanarayana, V.; Kumar, B. D.; Kanthikeyan, R. S.; Bhaskar, P.; Eur. J. Pharm. Sci. 2003, 19, 355.

80. Murthy, S. N.; Hiremath, S. R. R.; Paranjothy, K. L. K.; Int. J. Pharm. 2004, 272, 11 .

81. Sinha, V. R.; Mittal, B. R.; Bhutani, K K.; Kumria, R.; Int. J. Pharm. 2004, 269, 101.

82. Vendruscolo, C. W.; Andreazza, I. F.; Ganter, J. L. M. S.; Ferrero, C.; Bresolin, T. M. B.; Int. J. Pharm. 2005, 296, 1.

83. Coviello, T.; Alhaique, F.; Dorigo, A.; Matricardi, P.; Grassi, M.; Eur. J. Pharm. Biopharm. 2007, 66, 200.

84. George, M.; Abraham, T. E.; Int. J. Pharm. 2007, 335, 123.

85. Lopes, C. M.; Lobo, J. M. S.; Costa, P.; Braz. J. Pharm. Sci. 2005, 41, 143.

86. Peppas, N. A.; Sahlin, J. J.; Int. J. Pharm. 1989, 57, 169.

87. Vendruscolo, C. W.; Ferrero, C.; Pineda, E. A. G.; Ganter, J. L. M. S.; Freitas, R. A.; Jiménez- Castellanos, M. R.; Bresolin, T. M. B.; Carbohydr. Polym. 2009, 76, 86.

88. Reed, W. F.; Macromol. Chem. Phys. 1995, 196, 1539.

89. Wang, Q.; Huang, X.; Nakamura, A.; Burchard, W.; Hallet, F. R.; Carbohydr. Res. 2005, 340, 2637.

90. Baichwall, A.; Neville, D. A.; Drug Delivery Technololgy 2002, 2, 65.

91. Gliko-Kabir, I.; Yagen, B.; Penhasi, A.; Rubistein, A.; Pharm. Res. 1998, $15,1019$.

92. Gliko-Kabir, I.; Yage, B.; Penhasi, A.; Rubistein, A.; J. Controlled Release 2000, 63, 121.

93. Behari, K.; Kumar, R.; Tripathi, M.; Pandey, P. K.; Macromol. Chem. Phys. 2001, 202, 1873.

94. Reis, A. V.; Cavalcanti, O. A.; Rubira, A. F.; Muniz, E. C.; Int. J. Pharm. 2003, 267, 13 .
95. Singh, V.; Tiwari, A.; Tripathi, D. N.; Sanghi, R.; Carbohydr. Polym. 2004, 58, 1.

96. Cunha, P. L. R.; Castro, R. R.; Rocha, F. A. C.; de Paula, R. C. M.; Feitosa, J. P. A.; Int. J. Biol. Macromol. 2005, 37, 99.

97. Pandey, P. K.; Srivastava, A.; Tripathi, J.; Behari, K.; Carbohydr. Polym. 2006, 65, 414

98. Shi, H.-Y.; Zhang, L.-M.; Carbohydr. Polym. 2007, 67, 337.

99. Li, X.; Wu, W.; Liu, W.; Carbohydr. Polym. 2008, 71, 394.

100. Barbucci, R.; Pasqui, D.; Favaloro, R.; Panariello, G.; Carbohydr. Res. 2008, 343, 3058.

101. Lopes, A. L.; Andrade, C. T.; Milas, M.; Rinaudo, M.; Carbohydr. Polym. 1992, 17, 121.

102. Chandrasekaran, R.; Radha, A.; Carbohydr. Polym. 1997, 32, 201.

103. Goycoolea, F. M.; Foster, T. J.; Richardson, R. K.; Morris, E. R.; Gidley, M. J. In Gums and Stabilisers for the Food Industry; Williams, P. A.; Phillips, G. O. eds.; The Royal Society of Chemistry: Oxford, 1994.

104. Goycoolea, F. M.; Milas, M.; Rinaudo, M. In Gums and Stabilisers for the Food Industry; Williams, A. P.; Phillips, G. O., eds.; The Royal Society of Chemistry: Cambridge, 2000, vol. 10.

105. Goycoolea, F. M.; Milas, M.; Rinaudo, M.; Int. J. Biol. Macromol. 2001, $29,181$.

106. Bresolin, T. M.; Sander, P. C.; Reicher, F.; Sierakowski, M. R.; Rinaudo, M.; Ganter, J. L.; Carbohydr. Polym. 1997, 33, 131.

107. Bresolin, T.; Milas, M.; Rinaudo, M.; Ganter, J.; Int. J. Biol. Macromol. 1998, 23, 263.

108. Cronin, C. E.; Gianmouli, P.; McCleary, B. V.; Brooks, M.; Morris, E. R. In Gums and Stabilisers for the Food Industry; Williams, P. A.; Philips, G. O., eds.; The Royal Society of Chemistry: Cambridge, 2002, vol. 11.

109. Soppimath, K. S.; Kulkarni, A. R.; Aminabhavi, T. M.; J. Controlled Release 2001, 75, 331.

110. Thakur, S.; Chauhan, G. S.; Ahn, J.-H.; Carbohydr. Polym. 2009, 76, 513.

111. Yang, L.; Chu, J. S.; Fix, J. A.; Int. J. Pharm. 2002, 235, 1.

112. Kumar, P.; Mishra, B.; Curr. Drug Delivery 2008, 5, 186.

113. Vandamme, T. F. ; Lenourry, A.; Charrueau, C.; Chaumeil, J.-C.; Carbohydr. Polym. 2002, 48, 219.

114. Rubinstein, A.; Gliko-Kabir, I.; STP Pharma Science 1995, 5, 41.

115. Burke, M. D.; Park, J. O.; Srinivasarao, M.; Khan, S. A.; J. Controlled Release 2005, 104, 141.

116. Lee, S. S.; Lim, C. B.; Pai, C. M.; Lee, S. J.; Park, I.; Seo Moon, G.; Park, H. N.; EP pat. 974344 A2 1999. 